\title{
THE INFLUENCE OF GLUTATHIONE ON THE PROOXIDANT-ANTIOXIDANT ACTIVITY IN KIDNEYS AND BLOOD OF RATS WITH RHABDOMYOLYTIC MODEL OF ACUTE KIDNEY INJURY
}

The influence of glutathione on the prooxidant-antioxidant balance in rats' kidneys and blood under the conditions of rhabdomyolytic model of acute kidney injury was studied in the experiment. It is observed that intraperitoneal administration of glutathionein dose $30 \mathrm{mg} / \mathrm{kg}$ normalizes the prooxidant-antioxidant balance, confirmed by the reduction of lipid and protein peroxidation intensity, normalization of catalase and glutathione peroxidase activity, SH-groups andceruloplasmin content.

Key words: acute kidney injury; glutathione; prooxidant-antioxidant balance

\section{INTRODUCTION}

Rhabdomyolysis is a life-threatening clinical syndrome caused by the destruction of skeletal muscle with release of large amount of myoglobin into the bloodand development of acute kidney injury (AKI). The causes of rhabdomyolysis include muscular trauma, use of narcotics and some medicines, influence of toxins, infections, hyperthermia, seizures and electrolyte disturbances causing lysis of cells due to ischemia or acidosis. There are three pathogenetic mechanisms of rhabdomyolytic AKI: renal vasoconstriction, ischemia and oxidative stress,initiating cellular damage with disturbances of energy supply and metabolism.

It is estimated that $15 \%$ of AKI cases in the intensive care unitsare induced by rhabdomyolysis[11, 2, 14]. Therefore the search of remedies with nephroprotective properties able to prevent and correct this clinical syndrome is an important task of the modern medicine.

In this connection a potent antioxidant glutathione, providing the function of glutathione antioxidant system of the organism, have attracted our attention[1,15]. Glutathione is an oligopeptide consisting of glutamate, cysteine and glycine, and functioning as a hydrogen donator and cofactor of antioxidant enzymes, e.g. glutathione peroxidase.

The aim of research was to study out the influence of single glutathione administration on the processes of lipid and protein peroxidation under the conditions of rhabdomyolytic model of AKI.

(c) Drachuk V. M., Zamorskii I. I., Goroshko O. M., 2016

\section{MATERIALS AND METHODS}

Research was conducted on 21 non-linear adult white rats weighting 180-220 g. Animals were divided into 3 groups ( $\mathrm{n}=7)$ : I group - control, II group - pathology model. Animals of the III group received a glutathione after the modeling of rhabdomyolytic AKI. Pathology model was induced by intramuscular injection of $50 \%$ glycerol (10 ml/kg) [10]. Glutathione (TAD 600, "Biomedica Foscama”, Italy) was administered intraperitoneally at a dose of $30 \mathrm{mg} / \mathrm{kg} 40 \mathrm{~min}$ after glycerol injection. $24 \mathrm{~h}$ after the AKI modeling animals were decapitated under the ether anesthesia, blood and kidney samples were collected. Research was conducted accordingly to "European Convention on the protection of animals used for experimental and other scientific purposes" (Strasburg, 1986).

Malonedialdehyde (MDA) level in blood plasma and kidney tissue was determined by the reaction with 2-thiobarbituric acid [9], catalase (CAT) activity - by the reaction with ammonium molibdate [4], glutathione peroxidase (GPX) activity - by the amount of oxidized glutathione formed from reduced glutathione during the neutralization of hydrogen peroxide [1]. Ceruloplasmin (CP) level was estimated using the reaction of phenylenediamine oxidation [3]. Oxidatively modified proteins (OMP) level in kidney tissue was determined by formation of hydrazones by the interaction of the 2,4-dinitrophenylhydrazine with carbonyl groups [6]. SH-groups level in blood was estimated by the interaction of 5,5'-dithiobis2-nitrobenzoic acid (Ellman's reagent) with free SH-groups and formation of thionitrophenyl anion [7].

Statistical analysis was performed with Statistica 10.0 software. Group means were compared using parametric 


\begin{abstract}
THE INFLUENCE OF GLUTATHIONE ON THE PROOXIDANT-ANTIOXIDANT ACTIVITY IN KIDNEYS AND BLOOD OF RATS WITH RHABDOMYOLYTIC ACUTE KIDNEY INJURY (M $\pm \mathbf{m}, \mathbf{n}=7)$
\end{abstract}

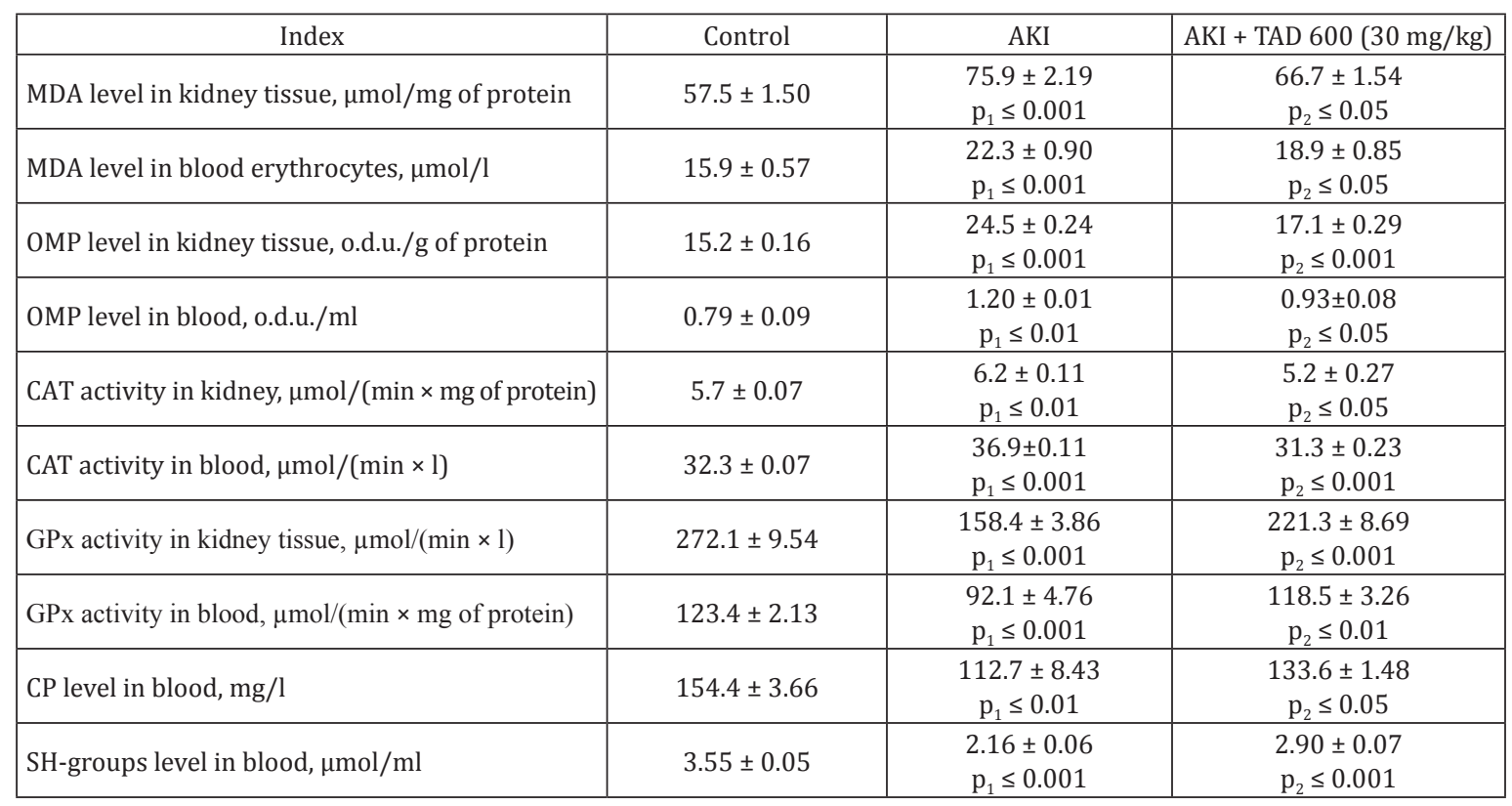

Note: $\mathrm{p}_{1}$ - index of significance comparing to control; $\mathrm{p}_{2}$ - index of significance comparing topathology model group.

Student's $t$-test (for normal distribution) and non-parametric Mann-Whitney $U$-test (in case of non-normal distributions). The level of significance was accepted with $\mathrm{p} \leq 0.05$.

\section{RESULTS AND DISCUSSION}

MDA is a main product of lipid peroxidation allowing an estimating the intensity of this process. An increase of its level by 1.3 times ( $\mathrm{p} \leq 0.001)$ in kidney tissue and by 1.4 times $(p \leq 0.001)$ in blood erythrocytes was observed in animals from pathology model group comparing to control (Table). Use of glutathione resulted in the decrease of MDA level by $12 \%(\mathrm{p} \leq 0.05)$ in kidney tissue and by $15 \%(\mathrm{p} \leq 0.05)$ in blood erythrocytes comparing to untreated animals.

Cytosolic proteins are the main targets for free radicals. Reduced glutathione and cysteine play important role in prevention of oxidative proteins modification, as their sulfhydryl groups are oxidized first. Due to the primary damaging effect and subsequent generation of active oxygen species OMP level in pathology model group was also increased by 1.6 times $(\mathrm{p} \leq 0.001)$ in kidney tissue and by 1.5 times ( $\leq 0.001)$ in blood plasma. Glutathione decreasedOMP level in kidney tissue by 1.4 times ( $\mathrm{p} \leq 0.001$ ) comparing to pathology model group. In blood plasma OMP level was reduced by 1.3 times ( $\mathrm{p} \leq 0.05)$ and restored to the control level.

Antioxidant system controls and inhibits all of the stages of free radicals reaction. Under the conditions of AKI a vasoconstriction and renal ischemia cause energy depletion and deficiency of energetic substrates for an- tioxidant enzymes, affecting the efficacy of protective systems. As previously stated, the glutathione system directly neutralizes active forms of oxygen and is especially important under the conditions of oxidative stress [8]. GPX activity depends on reduced glutathione content, which intracellular concentration is maintained by glutathione reductase. In its turn, glutathione reductase activity is determined by the reduced nicotinamide cofactors content [5]. In our research a significant decrease of GPX activity by 1.7 times ( $\mathrm{p} \leq 0.001)$ in kidney tissue and by 1.3 times $(p \leq 0.001)$ in blood plasma of rats from the II group was observed. In the group of animals undergoing the correction of AKI by glutathione a significant increase of enzymatic activity by 1.4 times ( $\mathrm{p} \leq 0.001)$ in kidney tissue and by 1.3 times( $\mathrm{p} \leq 0.01)$ in blood plasma comparing to pathology model group was established.

Acompensatory increase of CAT activity by $8 \%(p \leq 0.01)$ in kidneys and by $14 \%(\mathrm{p} \leq 0.001)$ in blood plasma was observed in pathology model group. In animals treated with glutathione CAT activity restored to the control indicesand was decreased by $16 \%(\mathrm{p} \leq 0.05)$ in kidney tissue and by $15 \%(\mathrm{p} \leq 0.001)$ in blood comparing to untreated pathology group.

Non-enzymatic part of antioxidant defense was estimated by the levels of ceruloplasmin and SH-groups in blood plasma. It was established that glutathione caused an increase in CP level by $19 \%$ (p $\leq 0.05)$, SH-groups level - by $34 \%(p \leq 0.01)$.

Thereby, use of glutathione with the aim of AKI correction caused a restoration of the antioxidant system activity and normalization of some indices. 
Research results testify to the protective effect of glutathione under the conditions of AKI. It is primarily provided by the potent antioxidant effect as glutathione is a key link in the three out of four existing antioxidant systems of the body [15].

\section{CONCLUSIONS}

1. An experimental rhabdomyolytic AKI is accompanied by an activation of the lipid and protein peroxidation in blood and kidney tissue.

2. Use of glutathione restores the prooxidant-antioxidant balance in rats with rhabdomyolytic AKI, causing a reduction of lipid peroxidation as well as protein free radical oxidation against the background normalization of antioxidant defense activity.

\section{REFERENCES}

1. Геруш I. В. Стан глутатіонової системи крові за умов експериментального виразкового ураження гастродуоденальної зони та дії настойки ехінацеї пурпурової / I. В. Геруш, I. Ф. Мещишен // Вісник проблем біол. та медицини. - 1998. - № 7. - С. 10-15.

2. Ермоленко В. М. Острая почечная недостаточность: [руководство] / В. М. Ермоленко, А. Ю. Николаев. - М.: ГЭОТАР-Медиа, 2010. - С. 40-49.

3. Колб В. Г. Справочник по клинической химии / В. Г. Колб, В. С. Камышников. - Мн: Беларусь, 1982. C. 311.

4. Королюк М. А. Метод определения активности каталазы / [М. А.Королюк, Л. И.Иванова, И. Г. Майорова и др.] // Лаб. дело. - 1988. - № 1. - С. 16-19.

5. Кулинський В. И. Ферментативное и неферментативное звено тиол-дисульфидной системы в головном мозге экспериментальных животных с церебральной ишемией: эффекты селеназы // Бюл. ВСНЦт СО РАМН. - 2005. - Т. 1, № 39. - С. 63-65.
6. Мещишен I. Ф. Метод визначення окислювальної модифікації білків плазми (сироватки) / І. Ф. Мещишен // Бук. мед. вісник. - 1998. - Т. 2, № 1. C. $156-158$.

7. Мещишен I. Ф. Метод кількісного визначення SHгруп у крові / І. Ф.Мещишен, Н. П. Григор'єва // Бук. мед. вісник. - 2002. - Т. 6, № 2. - С. 190-192.

8. Сибірна Н. О. Дослідження окремих біохімічних показників за умов оксидативного стресу: [навч.метод. посіб.] / Н. О. Сибірна, О. М. Маєвська, М. Л. Барська. - Львів: Вид. центр ЛНУ ім. І. Франка, 2006. - С. 60.

9. Стальная Л. Д. Метод определения малонового диальдегида с помощью тиобарбитуровой кислоты / Л. Д. Стальная, Т. Г. Гаришвили // Современные методы в биохимии. - М.: Медицина, 1977. - С. 66-68.

10. Штриголь С. Ю. Методи експериментального моделювання ураження нирок при фармакологічних дослідженнях: [метод. рекоменд. ДФЦ України] / [С. Ю. Штриголь, В. М. Лісовий, І. А. Зупанець та ін.]. - К., 2009. - С. 9-10.

11. Bosch X. Rhabdomyolysis and Acute Kidney Injury / X. Bosch, E. Poch, J. Grau // N. Engl. J. Med. - 2009. Vol. 361. - P. 62-72.

12. Halliwell B. Free radicals in Biology and Medicine / B. Halliwell, M. C. Gutteridge. - Oxford: Clarendon Press, 1989. - P. 320.

13. Ramani G. Oxidative stress and its association with cardiovascular risk in acute renal failure / G. Ramani, G. Kavitha, P. K. Dhass, R. Mary // Aruna Pharm. Bio Sci. - 2011. - Vol. 2, Iss. 3. - P. 329-334.

14. Vanholder R. Rhabdomyolysis / R. Vanholder, M. S. Sever, E. Erek, N. Lameire // J. Am. Soc. Nephrol. - 2000. Vol. 11. - P. 1553-1561.

15. Sies H. Glutathione and itsrolein cellular functions // Free Rad. Biol. Med. - 1999. - Vol. 29. - P. 916-921. 
УДК 616.61 - 001:615.31:547.466.64] - 092.9

В. М. Драчук, I. I. Заморський, О. М. Горошко

ВПЛИВ ПРЕПАРАТУ ГЛУТАТІОНУ НА ПРООКСИДАНТНО-АНТИОКСИДАНТНИЙ БАЛАНС У НИРКАХ ТА КРОВІ ЩУРІВ ПРИ РАБДОМІОЛІТИЧНІЙ МОДЕЛІ ГОСТРОГО ПОШКОДЖЕННЯ НИРОК

В експерименті досліджений вплив препарату глутатіону на прооксидантно-антиоксидантний баланс у нирках та крові щурів за умов рабдоміолітичної моделі гострого пошкодження нирок. При дії препарату спостерігали, що внутрішньоочеревинне введення глутатіону в дозі 30 мг/кг маси тіла тварин нормалізує баланс прооксидантно-антиоксидантних показників, що проявляється зменшенням інтенсивності пероксидного окиснення ліпідів і білків, нормалізацією активності каталази, глутатіонпероксидази, вмісту SH-груп та церулоплазміну.

Ключові слова: гостре пошкодження нирок; препарат глутатіону; прооксидантно-антиоксидантний баланс

УДК 616.61 - 001:615.31:547.466.64] - 092.9

В. М. Драчук, И. И. Заморский, А. М. Горошко

ВЛИЯНИЕ ПРЕПАРАТА ГЛУТАТИОНА НА ПРООКСИДАНТНО-АНТИОКСИДАНТНЫЙ БАЛАНС В ПОЧКАХ И КРОВИ КРЫС ПРИ РАБДОМИОЛИТИЧЕСКОЙ МОДЕЛИ ОСТРОГО ПОВРЕЖДЕНИЯ ПОЧЕК

В эксперименте исследовано влияние препарата глутатиона на прооксидантно-антиоксидантный баланс в почках и крови крыс в условиях рабдомиолитической модели острого повреждения почек. При действии препарата наблюдали, что внутрибрюшинное введение глутатиона в дозе 30 мг/кг массы тела животных нормализует баланс прооксидантно-антиоксидантных показателей, что проявляется уменьшением интенсивности пероксидного окисления липидов и белков, нормализацией активности каталазы, глутатионпероксидазы, содержания SH-групп и церулоплазмина.

Ключевые слова: острое повреждение почек; препарат глутатиона; прооксидантно-антиоксидантный баланс

Адреса для листування:

Надійшла до редакції 19.04.2016 p.

58002, м. Чернівці, Театральна пл., 2.

Тел. (0372) 55-37-54. E-mail: office@bsmu.edu.ua.

ДВНЗ України «Буковинський державний медичний

університет» 